\title{
Model to predict duty of community nurses in promotive and preventive care
}

\author{
Sismulyanto $^{1}$, Nursalam ${ }^{2}$, Ferry Efendi ${ }^{3}$, Made Mahaguna Putra ${ }^{4}$, Aditha Angga Pratama ${ }^{5}$ \\ ${ }^{1}$ Faculty of Health, Universitas Qamarul Huda, Indonesia \\ ${ }^{2,3}$ Faculty of Nursing, Universitas Airlangga, Indonesia \\ ${ }^{4,5}$ Sekolah Tinggi Ilmu Kesehatan Buleleng, Indonesia
}

\begin{tabular}{l} 
Article Info \\
\hline Article history: \\
Received May 27, 2018 \\
Revised Feb 02, 2019 \\
Accepted Feb 27, 2019
\end{tabular}

\section{Keywords:}

Community nurses

Preventive care

Promotive

\begin{abstract}
Community nurses has important role in promotive and preventive care in community. Aim of the study was to make model to predict community nurses role in promotive and preventive care based on Health Promotion Model (HPM). Design of the study was used explanatory with Cross-sectional approach. Sum of participant was 161. This study was conducted in 11 Public Health Center in Banyuwangi at 1 January to 30 January 2018. Methods of data collection was cluster sampling. The data was analysed using smart PLS software. Inner model: personal factors $(\mathrm{t}=1.981)$, interpersonal influences ( $\mathrm{t}=4.036)$, situational influences (5.720), commitment $(\mathrm{t}=5.138)$ had affected to community nurses duty in promotive and preventive care. This model could predict community nurses duty in promotive and preventive care in high level $(\mathrm{Q}=0.998)$. That was important to enhance of community nurses duty through modifying commitment of nurses, interpersonal influence factors, personal factors and situational influence factors.
\end{abstract}

Copyright () 2019 Institute of Advanced Engineering and Science. All rights reserved.

\section{Corresponding Author:}

Sismulyanto,

Faculty of Health,

Universitas Qamarul Huda,

Jalan H. Badaruddin-Bagu, Lombok Tengah, Kecamatan Pringgarata.

Email: sis_mulyanto@yahoo.com

\section{INTRODUCTION}

The increased prevalance of chronic disease offers nurses the challenge of how to help individuals make lifestyle changes and manage their conditions [1]. Internationally there has been growing interest in the public health role of primary care and how best to achieve a stronger orientation to prevention and health promotion services for patients [2-4]. Primary healthcare (PHC) focuses on the organisation and delivery of largely domiciliary services [5]. PHC is considered to be vital in the context of the National Health Service (NHS) as it represents a major contributor towards a care strategy that is efficient in the use of resources and in the effectiveness of its practices. PHC teams often provide the first contact with the patient and are integral to coordinating different services involved in care [6], they are also key providers of advice on health promotion and protection. Nurses working within PHC teams are involved in all aspects of primary care, from strategy to individual patient education and prevention [6]. The principles of Primary Health Care (PHC) such as efficiency and effectiveness in health service delivery; and equitable distribution of health services are identified as core elements with the potential to contribute to improved community health through properly coordinated district health systems [7].

The role and scope of nursing practice has evolved in response to the dynamic needs of individuals, communities, and healthcare services [8]. Health Promotion was an effort of communities' empowerment through counselling the community to promote health lifestyle choices. Implementing of health promoting 
behaviors include: taking responsibility for one's health, exercise and physical activity, spiritual involvement, proper nutrition, stress management, techniques and satisfying interpersonal relationship [9]. Meanwhile, health prevention was a kind of health care services that focusing on disease prevention (primary, secondary and tertiary level) through implementing of healthy lifestyle, conducting early disease screening, early disease treating, reducing impact of disease and rehabilitation [10].

Incidence of Dengue Haemoragic Fever (DHF) in Banyuwangi during the period 2016 reached 1300 cases with 11 cases of them was died. This number was increasing compared to 2015, which was 900 cases with 9 cases of which died worldwide. The High incidence of Dengue Haemoragic Fever (DHF) in community was caused by failure of implementation of health promotion and prevention in community. Kumat-Thome et al [11] reported that failure of implementation of health promotion and prevention in community caused by lack of community nurses's role to promote health lifestyle behaviors to community and unable to conduct intervention to prevent sickness. Whitehead [12] proved that majority of community nurses who giving health promotion in the community did not be supported by availability of regulation from regional government and community. Leak of sopporting system like poor of time, poor availability of facilities like computer etc. The purpose of the study was to analyses of (1) outer model that consisted of personal factors, interpersonal influences, situational influences, commitment of nurses, behavior, community nurses duty and outcome of health care. (2) outer model (3) Godness of fit.

\section{RESEARCH METHOD}

This study used explanatory reseach design and cross sectional approach. We used questionnare that was developed upon Health Promotion Model (HPM) as instrument to measure community nurses role and factors affected to community nurses role that consisted of personal factors, behavior related cogntion and effect, interpersonal influences, situational influences, and commitment of nurses. 1) Personal factors questionnare consisted of age, sex, education level and working period. 2) Behavior related cognition and effect questionnare consisted of cognitive aspect with 8 close ended questions and affective aspect with 10 close ended questions. 3) Interpersonal influences questionnare contained 16 close ended questions. 4) Situational influences questionnare contained 6 close ended questions. 5) Commitment contained 6 close ended questions, 6) Community nurses role questionnare contained 7 close ended questions.

In January 2018, 161 registered nurses working at 11 Public Health Center in Banyuwangi, Indonesia were invited to participate this study. Questionnare sheet that consisted of personal factors, behavior related cognition and effect, interpersonal influence, situational influence, commitment and community nurses role were distributed to nurses after willing as a participant. A participant must be met the inclusion criteria. Inclusion criteria were a nurse who worked at least one year experience in Public Health Center in Banyuwangi and having a health phyisic and mental condition. Descriptive analysis was conducted by displaying frequency distribution of each variable on the tables that consisted of frequency and percentage of each variable. We used smartPLS software to analysis of influence of independen variables (personal factors, behavior related cognition and effect, interpersonal influence, situational influence, commitment) to dependen variable (community nurses role in health promoting and preventing services). Result of this analysis was classified into two section: there was influence if $\mathrm{t}$-stat value was more than 1.96, there was not influence if $\mathrm{t}$-stat value was less than 1.96.

Outer model showed: 1) age, sex, and long of working was valid as indicators of personal factors, 2) knowledge and attitude was valid as indicators of behavior of nurses, 3) regulation and available of facility was valid as interpersonal influences, 4) affirmative, normative and contiunance was valid as indicators of commitment of nurses, 5) promotive and preventive care was valid as indicator of community nurses duty, 6) preventing and treating was valid as indicator of outcome of health care. This model could predict community nurses duty in promotive and preventive care in high level $(\mathrm{Q}=0.058)$. Inner model shown in Table 1 and hypothesis model shown in Table 2. 
Table 1. Inner model

\begin{tabular}{|c|c|c|c|c|}
\hline Variable & Sub variable & $\begin{array}{l}\text { Loading } \\
\text { factor }\end{array}$ & Information & $\begin{array}{l}\text { Composite } \\
\text { reliability }\end{array}$ \\
\hline \multirow{4}{*}{$\begin{array}{l}\text { Personal } \\
\text { factors }\end{array}$} & Age & 0.805 & Valid & \multirow{4}{*}{0.770} \\
\hline & Sex & 0.651 & Valid & \\
\hline & Education & 0.360 & Not valid & \\
\hline & Working time & 0.836 & Valid & \\
\hline \multirow{3}{*}{$\begin{array}{c}\text { Behavior } \\
\text { related } \\
\text { cognition and } \\
\text { effect }\end{array}$} & & & & \multirow{3}{*}{0.913} \\
\hline & Knowledge & 0.926 & Valid & \\
\hline & Attitude & 0.906 & Valid & \\
\hline \multirow{4}{*}{$\begin{array}{l}\text { Interpersonal } \\
\text { influences }\end{array}$} & Peer support & 0.838 & Valid & \multirow{4}{*}{0.889} \\
\hline & $\begin{array}{l}\text { 2. Other professions } \\
\text { support }\end{array}$ & 0.780 & Valid & \\
\hline & $\begin{array}{l}\text { 3. Chairman of } \\
\text { primary health } \\
\text { care support }\end{array}$ & 0.790 & Valid & \\
\hline & $\begin{array}{l}\text { 4. Community } \\
\text { support }\end{array}$ & 0.857 & Valid & \\
\hline \multirow{3}{*}{$\begin{array}{l}\text { Situational } \\
\text { influences }\end{array}$} & Policy & 0.949 & Valid & \multirow{3}{*}{0.946} \\
\hline & Facility & 0.946 & Valid & \\
\hline & Affirmative & 0.910 & Valid & \\
\hline \multirow[t]{2}{*}{ Commitment } & Normative & 0.858 & Valid & \multirow[t]{2}{*}{0.858} \\
\hline & Contuinance & 0.670 & Not Valid & \\
\hline \multirow{2}{*}{$\begin{array}{l}\text { Community } \\
\text { nurses duty }\end{array}$} & Promotive & 0.961 & Valid & \multirow{2}{*}{0.959} \\
\hline & Preventive & 0.959 & Valid & \\
\hline
\end{tabular}

Table 2. Hypothesis model

\begin{tabular}{|c|c|c|c|c|c|}
\hline Correlation between variable & $\begin{array}{l}\text { Original } \\
\text { sample }\end{array}$ & $\begin{array}{l}\text { Sample } \\
\quad \mathrm{X}\end{array}$ & $\begin{array}{l}\text { Standard Deviation } \\
\text { (STDEV) }\end{array}$ & $\begin{array}{c}\mathrm{T} \\
\text { Statistic }\end{array}$ & Information \\
\hline Personal factors $->$ behavior related cognition and effect & 0.631 & 0.643 & 0.054 & 9.709 & Significant \\
\hline Personal factors $->$ commitment & 0.631 & 0.643 & 0.054 & 2.430 & Significant \\
\hline Personal factors-> Interpersonal Influences & 0.659 & 0.668 & 0.050 & 8.951 & Significant \\
\hline Personal factors $->$ Situational Influences & 0.690 & 0.698 & 0.054 & 9.804 & Significant \\
\hline Personal factors-> Community nurses duty & 0.096 & 0.096 & 0.048 & 2.115 & Significant \\
\hline Behavior related cognition and effect-> commitment & 0.399 & 0.400 & 0.166 & 4.447 & Significant \\
\hline Interpersonal influences-> commitment & 0.257 & 0.267 & 0.150 & 2.554 & Significant \\
\hline Situational influences-> commitment & 0.248 & 0.241 & 0.093 & 5.548 & Significant \\
\hline $\begin{array}{c}\text { Behavior related cognition and effect-> Community } \\
\text { nurses duty }\end{array}$ & -0.121 & -0.126 & 0.068 & 2.875 & Significant \\
\hline Interpersonal influences-> Community nurses duty & 0.307 & 0.304 & 0.075 & 6.417 & Significant \\
\hline Situational influences-> Community nurses duty & 0.437 & 0.448 & 0.077 & 9.667 & Significant \\
\hline Commitment $->$ Community nurses duty & 0.338 & 0.329 & 0.060 & 8.062 & Significant \\
\hline
\end{tabular}

\section{RESULTS AND DISCUSSION}

Study result showed that commitment affected to community nurses role. commitment of nurses also showed on the positive level, that mean community nurses had a positive commitment to conduct their role on health promotive and preventive care to the community. The result of study was relevance with previous study that implementation of health promoting services in the community was influenced by commitment of community nurses and supported by organization culture [13]. Commitment could encourage a person to work fully dedication, having deseart to give his power and ability to work fully on purpose of organization so that could reach the optimum level [14].

Poghosyan et al. [15] also showed that commitment of nurse had contribute to achievement of promotive and preventive care in community. Nurses that had commitment to their self, organisation, and society could present a good promotive and preventive care behavior. Commitment was as a part of importance role of community nurses in giving promotive and preventive care to community. So that was needed an effort to enhance commitment of nurses. Study result showed that interpersonal influences affected to community nurses role. Interpersonal influences on the study also showed on the moderate level, that mean community nurses had a chance to conduct their role in giving health promotion and prevention services to community because they was supported by their nurses collegue, other health professional, chief of Public Health Center and community.

That was relevance with Pender [16] statement that the goal of health promoting and preventing efforts were depended by interpersonal influences that consisted of supporting of colleague, other health professional and community. Grant et al. [17] also reported supporting from colleague, other health 
profession, and community could optimise the community nurses role in giving promotive and preventive care to community and enhancing of community awareness to implement health life style behaviors [11].

Interpersonal influence that consisted of supporting from colleague, other health profession, and community was the factors that affected to commnity nurses role in giving promotive and preventive care to community. That was important to encourage community nurses always making good relationship with colleague, other profession and community. Study result showed that situational influences affected to community nurses role. Situational influences on the study also showed on the high category, that mean there were regulation related to implementation of health promotive and preventive services in the community and availability of facilities that supported promoting and preventing efforts.

Primary health care, on the other hand, is a public health strategy derived from the social model of health and is based on the philosophy that health gains are better obtained when people's basic needs are met first [18]. The fundamental principles of primary health care at the operational level are unique to the specific circumstances or system. Thus the underlying social determinants on ill-health such as access to basic living conditions, unemployment, etc are important factors to consider in the primary health care strategy. The strength of primary health care is to respond to the local needs of individuals, families and populations through a comprehensive, inter-sectoral approach that focuses on communities as the unit of intervention. In essence, primary health care provides a connection between health and health care, by linking this to social and economic systems. The principles of the primary health care approach include equity in health service delivery, access to affordable and appropriate services, empowerment of people, and sustainability of service provision [19].

That was relevance with Pender [16] statement that the goal of health promoting and preventing efforts were depended by situational influences that consisted of availability of regulation and facilities. Thomas et al. [10] reported that situational influences that support implementation of promotive and preventive care in community was regulation and availabilty of facilities. Regulation could guide the community nurses about the scope that should be done and ensure the community nurses from many kinds of duty accident [20]. Whitehead [12] also proved that availability of regulation and facilties had influenced to implementation of promotive and preventive care in community. Situational influences that consisted of regulation and facilities was a part of importance role of community nurses in promotive and preventive care. To enhance affected of situational influences, could be done by ensure of availabity of regulation and facilities.

\section{CONCLUSION}

Community nurses of Primary Health Care in Banyuwangi conducted promotive and preventive care to community goodly enough. Commitment of nurses, interpersonal influences, and situational influences were factors that affected to community nurses role in promotive and preventive care. It was considered to enhance of community nurses role capacity through modifying commitment of nurses, interpersonal influence factors and situational influence factors.

\section{ACKNOWLEDGEMENTS}

The authors would like to thank to all participants who participated in this study.

\section{REFERENCES}

[1] K. Davies, "What is effective intervention? - using theories of health promotion," Br. J. Nurs., vol. 15, no. 5, pp. 252-256, 2006.

[2] World Health Organization, Primary care: now more than ever. Geneva: WHO, 2005.

[3] World Health Organization, Declaration of Alma Ata. International conference on primary care. Alma Ata: USSR, 1978.

[4] S. Peckham, A. Hann, S. Kendall, and S. Gillam, "Health promotion and disease prevention in general practice and primary care: a scoping study," Prim. Heal. Care Res. Dev., vol. 18, no. 6, pp. 529-540, 2017.

[5] R. Kuschnir and A. H. Chorny, "Redalyc Redes de atenção à saúde: contextualizando o debate Health care networks : contextualizing the debate," Cien. Saude Colet., vol. 15, no. 5, 2010.

[6] C. R. Dalla Nora, R. Schaefer, and J. Neves-Amado, "Nurses' practices in the context of primary healthcare in Portugal," J. Res. Nurs., vol. 23, no. 6, pp. 520-532, 2018.

[7] N. Phaswana-Mafuya et al., "Primary health care service delivery in South Africa," Int. J. Health Care Qual. Assur., vol. 21, no. 6, pp. 611-624, Sep. 2008.

[8] S. Randall, T. Crawford, J. Currie, J. River, and V. Betihavas, "Impact of community based nurse-led clinics on patient outcomes, patient satisfaction, patient access and cost effectiveness: A systematic review," Int. J. Nurs. Stud., vol. 73, no. May, pp. 24-33, 2017. 
[9] S. Fuller, "Illness prevention in the NHS five year forward view," Nurs. Manage., vol. 22, no. 3, pp. 20-26, May 2015.

[10] J. J. Thomas, A. M. Hart, and M. E. Burman, "Improving Health Promotion and Disease Prevention in NPDelivered Primary Care," J. Nurse Pract., vol. 10, no. 4, pp. 221-228, 2014.

[11] E. Kurnat-Thoma, M. El-Banna, M. Oakcrum, and J. Tyroler, "Nurses' health promoting lifestyle behaviors in a community hospital," Appl. Nurs. Res., vol. 35, pp. 71-81, 2017.

[12] D. Whitehead, "The role of community-based nurses in health promotion," Br. J. Community Nurs., vol. 5, no. 12, pp. 604-609, 2000.

[13] B. Garry et al., "Promotion of oral health by community nurses," Br. J. Community Nurs., vol. 22, no. 10, 2017.

[14] V. Maijala, K. Tossavainen, and H. Turunen, "Health promotion practices delivered by primary health care nurses : Elements for success in Finland," Appl. Nurs. Res., vol. 30, pp. 45-51, 2016.

[15] L. Poghosyan, J. Liu, and A. A. Norful, "Nurse practitioners as primary care providers with their own patient panels and organizational structures : A cross-sectional study," Int. J. Nurs. Stud., vol. 74, no. December 2016, pp. $1-7,2017$.

[16] N. J. Pender, C. L. Murdaugh, and M. A. Parsons, Health promotion in nursing practice. Pearson, 2011.

[17] A. J. Grant, L. Lines, P. Darbyshire, Y. Parry, L. Lines, and P. Darbyshire, "How do nurse practitioners work in primary health care settings? A scoping review," Int. J. Nurs. Stud., 2017.

[18] H. Keleher, "Why Primary Health Care Offers a more Comprehensive Approach to Tackling Health Inequities than Primary Care," Aust. J. Prim. Health, vol. 7, no. 2, p. 57, 2001.

[19] C. van Weel and J. De Maeseneer, "Now more than ever: World Health Assembly revisits primary health care," Prim. Health Care Res. Dev., vol. 11, no. 01, p. 1, Jan. 2010.

[20] W. Tingvoll, T. Sæterstrand, and L. M. Mcclusky, "The challenges of primary health care nurse leaders in the wake of New Health Care Reform in Norway," BMC Nurs., pp. 1-8, 2016. 